\title{
Correction to: Circular economy assessment tool for end of life product recovery strategies
}

\author{
Yohannes A. Alamerew ${ }^{1}$ - Daniel Brissaud ${ }^{1}$
}

Published online: 27 April 2019

(C) The Author(s) 2019

\section{Correction to: Journal of Remanufacturing https://doi.org/10.1007/s13243-018-0064-8}

The article "Circular economy assessment tool for end of life product recovery strategies", written by Yohannes A. Alamerew and Daniel Brissaud, was originally published electronically on the publisher's internet portal (currently SpringerLink) on 31 October 2018 without open access.

With the author(s)' decision to opt for Open Choice the copyright of the article changed on April 2019 to (C) The Author(s) 2018 and the article is forthwith distributed under the terms of the Creative Commons Attribution 4.0 International License (http://creativecommons. org/licenses/by/4.0/), which permits use, duplication, adaptation, distribution and reproduction in any medium or format, as long as you give appropriate credit to the original author(s) and the source, provide a link to the Creative Commons license and indicate if changes were made.

The original article has been corrected.

Publisher's note Springer Nature remains neutral with regard to jurisdictional claims in published maps and institutional affiliations.

The online version of the original article can be found at https://doi.org/10.1007/s13243-018-0064-8

Yohannes A. Alamerew

yohannes.alamerew@grenoble-inp.fr

1 Univ. Grenoble Alpes, CNRS, G-SCOP, 38000 Grenoble, France 